\title{
153. Tracheobronchiales Absaugen als Problem der Intensivbehandlung
}

\author{
Fortlaufende $\mathrm{pO}_{2}$-Messungen \\ mit einer polarographischen Mikromethode \\ während verschiedener tracheobronchialer Absaugmanöver
}

\author{
G. Hempelmank*, W. HaRtmanN, H. Fabei, K. H. Leitz \\ und W. J. NoLTE-Hannover
}

\section{Tracheobronchial Suction as a Problem of Intensive Care}

Summary. It is reported on continuous oxygen-tension-monitoring during tracheobronchial suction in 10 surgical patients being on respirator treatment. Without additional oxygen prior to suction $p \mathrm{O}_{2}$ dropped to $61,8(\operatorname{method} 1)$ and 61,4 Torr (method 2). Inflation of the lungs by respirator with an extra-pressure of $10 \mathrm{~cm} \mathrm{H}_{2} \mathrm{O}$ did not show a significantly more rapid $p \mathrm{O}_{2}$-increase. $100 \%$ oxygen for $1 \mathrm{~min}$ prior to suction led to a $p \mathrm{O}_{2}$-minimum of only 81,2 Torr. General advices for tracheobronchial suction are given.

Zusammenfassung. Mit einer polarographischen Mikromethode wurde der Sauerstoffpartialdruck kontinuierlich während verschiedener tracheobronchialer Absaugmanöver bei 10 beatmeten Patienten gemessen. Dabei zeigte sich, daß ohne vorherige Sauerstoffgabe der $p \mathrm{O}_{2}$ im Mittel auf 61,8 bzw. 61,4 Torr herabfiel.

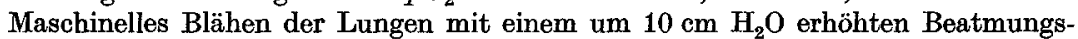
druck führte nicht zu einem signifikant schnelleren $p \mathrm{O}_{2}$-Anstieg. Sauerstoffbeatmung vor dem Absaugen führte zu einem $\mathrm{pO}_{2}$-Minimum von nur 81,2 Torr. Abschließend werden allgemeine Richtlinien für tracheobronchiales Absaugen gegeben.

\section{Behandlung des zentralbedingten Lungenödems von Unfallverletzten}

\author{
D. Maroske*, H. Pelzl und H. Drews-Marburg
}

Therapy of Pulmonary Edema Following Head Injury

Summary. In the last 3 years it was found that only 7 patients out of 450 patients with head injuries developed pulmonary edema. The age range of these patients was from 4 to 35 years old.

Only 2 of these patients suffered from head injury alone. Of the other 5 patients all showed fractures of the extremities, and in 2 of these patients compounded contusio of the lung or rib fractures were found. In the latter a ruptured spleen was also present. In 2 of the 7 patients evidence of shock was exhibited. Pulmonary edema was developed in 5 patients within the first 50 min after the accident. The other 2 patients developed pulmonary edema 40 and $52 \mathrm{~h}$ later. 